\title{
Invigorasi Osmoconditioning dengan Kalsium Klorida untuk Perbaikan Mutu Fisiologis Benih Padi Hitam Lokal (Oryza sativa L.)
}

\section{Osmoconditioning Invigoration with Calcium Chloride for Physiologic Quality Improvement of Upland Black Rice Seed (Oryza sativa L.)}

\author{
Chailendriani Pradaneira Anwar, Prapto Yudono*) \\ Departemen Budidaya Pertanian, Fakultas Pertanian, Universitas Gadjah Mada \\ *) Penulis untuk koresponden Email: prapto_yudhono@ugm.ac.id
}

\begin{abstract}
Generally farmers of upland black rice used the seed that were harvested and stored from the previous season. Seed deterioration is a process that always occur and cannot be reversed. Osmoconditioning with calcium chloride $\left(\mathrm{CaCl}_{2}\right)$ is known to increase $\alpha$-amylase activity which plays a role in germination and supports seedling growth. This research aimed to determine the differences in physiological quality of upland black rice seeds which were treated and untreated with osmoconditioning calcium chloride with new black seed, to determine the immersion time and the optimal concentration of calcium chloride and the best combination of treatments for the physiological quality of local black rice seeds that have been stored. The research was conducted at Teknologi Benih Laboratorium and Greenhouse in Tridharma Banguntapan Experimental Farm, Universitas Gadjah Mada on March until May 2018, used 1 and 7 months stored seed. The experiment was arranged in factorial completed randomized design. The first factor was the soaking time of 6,12 and 24 hours. The second factor was the concentration of $\mathrm{CaCl}_{2}$ (control, 1.5, 3, 4.5, and $6 \%$ ), with 1 month and 7 months stored seed as control without treatment. The results showed that calcium chloride 1.887-3.161\% was optimum for fresh and dry weight of seedling, increasing the hypothetical seed vigor index of stored local black rice seed; beside that 12 hours immersion time with $1.5 \% \mathrm{CaCl}_{2}$ were the best combination of treatments for root length, and 12 hours with $3 \% \mathrm{CaCl}_{2}$ were the best on stem diameter.
\end{abstract}

Keywords: upland rice seed; $\mathrm{CaCl}_{2}$; invigoration; osmoconditioning

\section{INTISARI}

Umumnya hasil panen benih padi hitam lokal musim sebelumnya disimpan untuk digunakan pada pertanaman selanjutnya. Deteriorasi atau kemunduran benih pada saat penyimpanan benih merupakan proses yang pasti terjadi dan tidak dapat balik. Invigorasi osmoconditioning dengan kalsium klorida $\left(\mathrm{CaCl}_{2}\right)$ diketahui mampu meningkatkan aktivitas a-amilase yang berperan dalam perkecambahan dan mendukung pertumbuhan bibit. Penelitian ini bertujuan untuk mengetahui perbedaan mutu fisiologis benih padi hitam lokal lama yang diberi perlakuan osmoconditioning kalsium klorida dengan benih hitam baru, mengetahui lama perendaman dan konsentrasi kalsium klorida yang optimal serta kombinasi perlakuan terbaik terhadap mutu fisiologis benih padi hitam lokal yang telah 
dilakukan penyimpanan. Penelitian ini dilaksanakan di Laboratorium Teknologi Benih dan Rumah Kaca Kebun Tridharma Banguntapan, Universitas Gadjah Mada pada bulan Maret sampai Mei 2018. Penelitian ini menggunaan benih yang telah disimpan 1 bulan (baru) dan 7 bulan (lama). Desain penelitian yang digunakan adalah rancangan acak lengkap (RAL) faktorial. Faktor pertama yaitu lama perendaman 6, 12, dan 24 jam. Faktor kedua konsentrasi $\mathrm{CaCl}_{2}$ (kontrol; 1,$5 ; 3 ; 4,5$; dan $6 \%$ ), dengan kontrol benih baru dan lama tanpa perlakuan. Hasil penelitian menunjukkan bahwa konsentrasi $\mathrm{CaCl}_{2}$ pada kisaran 1,887-3,161 \% optimal terhadap parameter bobot segar bibit, bobot kering bibit, dan meningkatkan indeks vigor hipotetik bibit pada benih padi hitam lokal lama, serta lama perendaman 12 jam dengan 1,5\% $\mathrm{CaCl}_{2}$ memberikan nilai panjang akar terbaik, sedangkan lama perendaman 12 jam dengan $3 \% \mathrm{CaCl}_{2}$ memberikan nilai terbaik pada diameter batang.

Kata kunci: benih padi local; $\mathrm{CaCl}_{2}$; invigorasi; osmoconditioning

\section{PENDAHULUAN}

Tanaman padi (Oryza sativa L.) merupakan salah satu tanaman pangan yang menjadi komoditas penting pada berbagai negara, khususnya negara Indonesia karena beras menjadi salah satu sumber makanan pokok bagi masyarakat di Indonesia. Menurut Kim et al. (2015) tanaman padi merupakan salah satu tanaman serealia yang dikonsumsi sekitar 89 \% masyarakat di negara-negara Asia sebagai makan pokok. Sementara di Indonesia terdapat sekitar $95 \%$ penduduk yang mengonsumsi beras sebagai bahan makanan pokok (Agus, 2007).

Selain beras putih, terdapat berbagai macam beras lain yang telah dikenal di Indonesia, salah satunya adalah beras hitam yang telah dikenal oleh masyarakat memiliki berbagai manfaat bagi kesehatan. Selain memiliki potensi dalam bidang kesehatan, padi beras hitam berpotensi secara ekonomi karena harganya yang lebih mahal daripada beras putih, serta memiliki potensi genetik. Salah satu beras hitam lokal Sleman, Yogyakarta terdaftar sebagai varietas lokal Sleman Nomor 201/PVHP/2016 dengan nama Sembada Hitam (BPTP Yogyakarta, 2017).

Pada umumnya penanaman padi lokal menggunakan benih dari pertanaman sebelumnya, sehingga perlu adanya penyimpanan benih. Apabila benih disimpan dalam jangka waktu lama maka berpotensi akan menurunnya mutu benih. Kemunduran benih dapat berdampak pada rendahnya presentase bibit yang tumbuh dan menyebabkan pertumbuhan yang tidak seragam, sehingga dapat mempengaruhi hasil panen. Perlu adanya perlakuan benih untuk mempersiapkan benih dengan mutu yang baik sebelum 
benih ditanam di lapangan, hal tersebut dapat dilakukan dengan menerapkan teknologi invigorasi benih. Invigorasi benih dapat memperbaiki benih dalam kaitannya dengan viabilitas benih.

Invigorasi benih merupakan perlakuan yang dilakukan untuk memperbaiki fisiologis dan biokimiawi benih yang berhubungan dengan keserempakan, kecepatan, serta peningkatan kemampuan benih untuk berkecambah (Sutariati et al., 2014). Selain berpengaruh dalam memperbaiki viabilitas benih, perlakuan invigorasi benih juga dapat meningkatan produktivitas tanaman. Beberapa metode yang diketahui efektif dalam invigorasi benih adalah osmoconditioning, hidrasi-dehidrasi, serta matriconditioning (Kartika dan Sari, 2015). Pada osmoconditioning dapat dilakukan dengan menggunakan larutan osmotik seperti polyethylen glycol (PEG), $\mathrm{KNO}_{3}, \mathrm{CaCl}_{2}, \mathrm{~K}_{3} \mathrm{PO}_{4}, \mathrm{NaCl}$, dan manitol (Khan, 1992).

Berdasarkan penelitian Singh et al. (2017) priming dengan larutan $\mathrm{CaCl}_{2} 1 \%$ selama 12 jam mampu meningkatkan perkecambahan dan vigor benih gandum. Selain itu Farooq et al. (2007) juga memperoleh hasil positif dari penggunaan $\mathrm{CaCl}_{2}$ selama 24 jam sebagai osmohardening (hidrasi-dehidrasi berulang dengan larutan osmotik) dapat meningkatkan produksi produksi dan indeks panen padi, serta berkorelasi positif dengan persentase perkecambahan, bobot segar dan bobot kering bibit. Selain itu invigorasi osmoconditioning dengan $\mathrm{CaCl}_{2}$ diketahui mampu meningkatkan aktivitas enzim yang berperan dalam perkecambahan. Invigorasi benih dengan osmoconditioning dapat menjadi salah satu upaya untuk meningkatkan mutu benih padi lokal yang telah disimpan dalam jangka waktu tertentu, sehingga penelitian mengenai invigorasi benih dengan metode osmoconditioning beserta kaitannya dengan lama perendaman dan konsentrasi larutan $\mathrm{CaCl}_{2}$ pada benih padi lokal perlu dilakukan.

\section{BAHAN DAN METODE PENELITIAN}

Penelitian dilaksanakan di Laboratorium Teknologi Benih dan Rumah Kaca Kebun Tridharma Banguntapan, Universitas Gadjah Mada pada bulan Maret - Mei 2018. Alat-alat yang digunakan meliputi petridish, bak-bak persemaian, timbangan analitik, leaf area meter, oven, gelas beaker, pinset, gelas ukur, sprayer, penggaris, germinator, kertas filter, kapas, dan alat tulis. Adapun bahan yang digunakan dalam penelitian ini yaitu benih padi hitam lokal Sembada Hitam (lokal Sleman) lama (umur simpan 7 bulan) dan benih baru 
(umur simpan 1 bulan) yang digunakan sebagai pembanding, kalsium klorida $\left(\mathrm{CaCl}_{2}\right)$, media tanam, serta aquades.

Penelitian ini disusun menggunakan Rancangan Acak Lengkap Faktorial dengan dua faktor. Faktor pertama yaitu lama perendaman yang terdiri dari 3 taraf, L1= 6 jam, L2= 12 jam, dan $\mathrm{L} 3=24$ jam, sedangkan faktor kedua yaitu konsentrasi larutan $\mathrm{CaCl}_{2}$ yang terdiri dari $\mathrm{K} 0=$ kontrol (tanpa perlakuan), $\mathrm{K} 1=1,5 \%, \mathrm{~K} 2=3 \%, \mathrm{~K} 3=4,5 \%, \mathrm{~K} 4=6 \%$. Perlakuan adalah hasil kombinasi antar faktor dari seluruh taraf perlakuan. Data yang diperoleh dianalisis menggunakan analisis varian (ANOVA) pada tingkat $5 \%$, untuk membandingkan antara benih baru dan benih lama dilanjutkan dengan uji lanjut kontras orthogonal. Jika hasil analisis varian, untuk perlakuan lama perendaman dan konsentrasi larutan $\mathrm{CaCl}_{2}$ pada benih lama menunjukkan adanya interaksi dilanjutkan uji pengaruh sederhana per aras faktor utama, jika tidak ada interaksi dilakukan uji perbandingan rerata untuk masing-masing faktor dengan uji HSD.

\section{HASIL DAN PEMBAHASAN}

Salah satu cara untuk mendeteksi viabilitas benih adalah dengan melakukan pengujian mutu fisiologis benih. Parameter untuk mendeteksi viabilitas benih tersebut meliputi viabilitas potensial dan vigor benih. Deteriorasi akan mengakibatkan benih memiliki viabilitas dan vigor benih yang kurang baik, sehingga perlu adanya upaya agar viabilitas dan vigor benih menjadi lebih baik. Alternatif yang dapat digunakan untuk mengatasi mutu benih yang rendah adalah dengan dilakukan perlakuan invigorasi dengan priming. Perlakuan priming telah terbukti bermanfaat dalam invigorasi benih selama penyimpanan, selain itu juga dapat meningkatkan, mempercepat dan menyeragamkan perkecambahan serta pembentukan bibit, mengatasi atau mengurangi berbagai tipe dormansi, serta meningkatkan perkecambahan dan pembentukan bibit pada kondisi lingkungan yang tidak menguntungkan. Manfaat dari priming tidak terkhusus pada tahap perkecambahan saja, namun dapat berdampak pada fase selanjutnya, yaitu dengan meningkatkan tolensi terhadap perbedaan tekanan biotik dan abiotik (Castanares \& Bouzo, 2017).

Tabel 1. Uji kontras ortogonal umur simpan benih terhadap panjang akar kecambah 
Anwar dan Yudono / Vegetalika. 2019. 8(3): 166-176

\begin{tabular}{lccc}
\hline Benih Baru vs Benih Lama & Benih Baru & Benih Lama & $*$ \\
Benih lama & 7.533 & 6.147 & \\
(Kontrol vs Perlakuan) & Kontrol & Perlakuan & tn \\
\hline
\end{tabular}

Keterangan: $\left({ }^{*}\right)$ berbeda nyata, $(\mathrm{tn})$ tidak berbeda nyata $(\alpha=5 \%)$

Tabel 2. Panjang akar kecambah pada berbagai perlakuan lama perendaman dan konsentrasi larutan kalsium klorida

\begin{tabular}{|c|c|c|c|c|c|c|c|c|c|}
\hline Perlakuan & \multicolumn{2}{|c|}{ K1 (1.5\%) } & \multicolumn{2}{|c|}{ K2 (3 \%) } & \multicolumn{2}{|c|}{ K3 (4.5 \%) } & \multicolumn{2}{|c|}{ K4 (6 \%) } & Rerata \\
\hline L1 (6 jam) & 5.888 & $a b$ & 5.163 & $\mathrm{~b}$ & 6.365 & $a b$ & 6.728 & $a b$ & 6.036 \\
\hline L2 (12 jam) & 7.168 & a & 6.080 & $a b$ & 5.935 & $a b$ & 5.133 & $\mathrm{~b}$ & 6.079 \\
\hline L3 (24 jam) & 6.280 & $a b$ & 6.560 & $a b$ & 6.268 & $a b$ & 6.310 & $a b$ & 6.354 \\
\hline Rerata & 6.445 & & 5.934 & & 6.189 & & 6.057 & & $(+)$ \\
\hline
\end{tabular}

Keterangan: $(+)$ menunjukkan ada interaksi, angka rerata yang diikuti huruf yang sama menunjukkan tidak berbeda nyata pada uji HSD ( $\alpha=5 \%)$

Tabel 1 menunjukkan adanya beda nyata antara benih baru dengan benih lama, sedangkan benih lama kontrol dengan perlakuan tidak berbeda nyata, hal ini dapat berkaitan dengan vigor benih baru yang diduga lebih baik daripada benih lama. Adanya interaksi antara lama perendaman dan konsentrasi terhadap panjang akar kecambah ditunjukkan pada Tabel 2. Hasil panjang akar kecambah terbaik dapat dilihat pada konsentrasi larutan $\mathrm{CaCl}_{2} \quad 1,5 \%$ dengan lama perendaman benih selama $12 \mathrm{jam}$. Selanjutnya dari tabel tersebut dapat dilihat bahwa panjang akar terendah ditunjukkan pada perlakuan $6 \% \mathrm{CaCl}_{2}$ dengan lama perendaman $12 \mathrm{jam}$. Apabila konsentrasi kalsium klorida semakin tinggi, maka hal tersebut justru dapat meracuni benih dan menyebabkan metabolisme di dalam benih dapat terganggu, serta mempengaruhi perkecambahan benih, termasuk dalam pembentukan akar kecambah.

Tabel 3. Uji kontras ortogonal umur simpan benih terhadap diameter batang

\begin{tabular}{lccc}
\hline \multicolumn{1}{c}{ Komponen Kontras Ortogonal } & Perbandingan Diameter Batang & Keterangan \\
\hline Benih Baru vs Benih Lama & Benih Baru & Benih Lama & tn \\
Benih lama & 0.159 & 0.173 & \\
(Kontrol vs Perlakuan) & Kontrol & Perlakuan & $*$
\end{tabular}

Keterangan: $\left({ }^{*}\right)$ berbeda nyata, $(\mathrm{tn})$ tidak berbeda nyata $(\alpha=5 \%)$ 
Tabel 4. Diameter batang pada berbagai perlakuan lama perendaman dan konsentrasi larutan kalsium klorida

\begin{tabular}{|c|c|c|c|c|c|c|c|c|c|}
\hline Perlakuan & \multicolumn{2}{|c|}{ K1 (1.5\%) } & \multicolumn{2}{|c|}{ K2 (3 \%) } & \multicolumn{2}{|c|}{ K3 (4.5\%) } & \multicolumn{2}{|c|}{ K4 (6 \%) } & Rerata \\
\hline L1 (6 jam) & 0.171 & $a-d$ & 0.214 & $a b$ & 0.191 & $a b c$ & 0.149 & $\mathrm{~cd}$ & 0.182 \\
\hline L2 (12 jam) & 0.175 & $a-d$ & 0.219 & a & 0.167 & bcd & 0.141 & d & 0.176 \\
\hline L3 (24 jam) & 0.182 & $a-d$ & 0.176 & $a-d$ & 0.178 & $a-d$ & 0.171 & a-d & 0.177 \\
\hline Rerata & 0.176 & & 0.203 & & 0.179 & & 0.154 & & $(+)$ \\
\hline Koefisien Ker & $\operatorname{man}(\%)$ & & & & & 9.6 & & & \\
\hline
\end{tabular}

Tidak beda nyata antara benih baru dengan benih lama, namun terdapat beda nyata pada benih lama kontrol dengan perlakuan dapat dilihat pada hasil uji kontras ortogonal umur simpan benih terhadap diameter batang (Tabel 3). Hal ini menunjukkan bahwa dari perlakuan memberikan nilai diameter batang yang lebih besar daripada benih lama tanpa perlakuan. Dapat diketahui terdapat interaksi antar perlakuan terhadap diameter batang yang ditunjukkan pada Tabel 4. Pada tabel tersebut dapat dilihat bahwa hasil diameter batang terbaik dapat dilihat dari kombinasi perlakuan konsentrasi larutan $\mathrm{CaCl}_{2} 3 \%$ dengan lama perendaman benih selama 12 jam.

Tabel 5. Uji kontras ortogonal umur simpan benih terhadap bobot segar bibit

\begin{tabular}{lccc}
\hline \multicolumn{1}{c}{ Komponen Kontras Ortogonal } & \multicolumn{1}{c}{ Perbandingan } & Bobot Segar Bibit & Keterangan \\
\hline Benih Baru vs Benih Lama & Benih Baru & Benih Lama & tn \\
Benih lama & 0.193 & 0.228 & \\
(Kontrol vs Perlakuan) & Kontrol & Perlakuan & $*$ \\
& 0.179 & 0.233 & \\
\hline
\end{tabular}

Keterangan: $\left(^{*}\right)$ berbeda nyata, (tn) tidak berbeda nyata $(\alpha=5 \%)$

Tabel 6. Uji kontras ortogonal umur simpan benih terhadap bobot kering bibit

\begin{tabular}{|c|c|c|c|}
\hline $\begin{array}{c}\text { Komponen Kontras } \\
\text { Ortogonal }\end{array}$ & \multicolumn{2}{|c|}{ Perbandingan Bobot Kering Bibit } & Keterangan \\
\hline Benih Baru vs Benih Lama & $\begin{array}{c}\text { Benih Baru } \\
0.058\end{array}$ & $\begin{array}{c}\text { Benih Lama } \\
0.066\end{array}$ & tn \\
\hline \multirow{2}{*}{$\begin{array}{l}\text { Benih lama } \\
\text { (Kontrol vs Perlakuan) }\end{array}$} & Kontrol & Perlakuan & \multirow[b]{2}{*}{ * } \\
\hline & 0.052 & 0.067 & \\
\hline
\end{tabular}

Keterangan: $\left(^{*}\right)$ berbeda nyata, (tn) tidak berbeda nyata $(\alpha=5 \%)$

Tabel 5 dan 6 menunjukkan tidak adanya beda nyata antara benih baru dengan benih lama, sedangkan benih lama kontrol dengan perlakuan terdapat beda nyata. Hal ini menunjukkan bahwa dari perlakuan memberikan nilai bobot segar dan bobot kering yang lebih tinggi daripada benih lama tanpa perlakuan. Guna melihat konsentrasi kalsium 
klorida yang optimal terhadap bobot segar bibit dilakukan analisis regresi seperti pada Gambar 1.

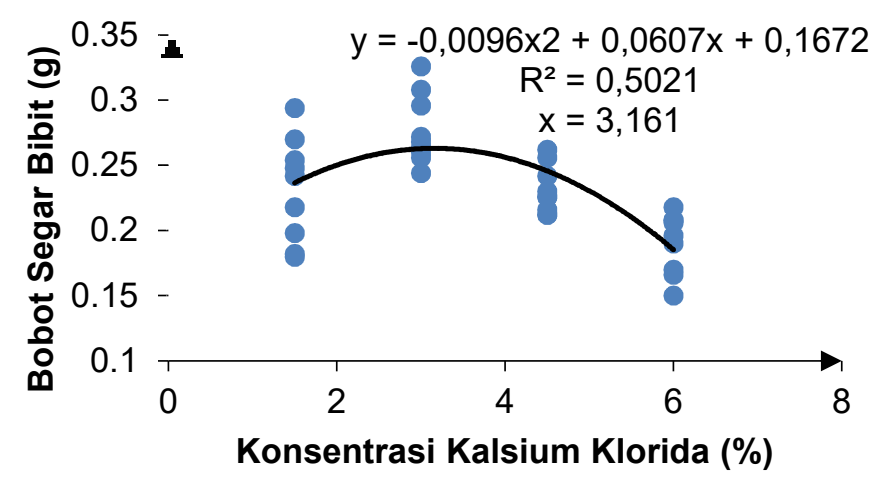

Gambar 1. Pengaruh konsentrasi kalsium klorida terhadap bobot segar bibit

Grafik pengaruh konsentrasi kalsium klorida terhadap bobot segar bibit disajikan pada Gambar 1. Tidak terdapat interaksi antara lama perendaman dan konsentrasi kalsium klorida $\left(\mathrm{CaCl}_{2}\right)$. Hubungan regresi antara konsentrasi kalsium klorida dengan bobot segar bibit terjadi secara nyata. Berdasarkan Gambar 1. tersebut dapat dilihat persamaan dari regresi kuadratik, yaitu $y=-0,0096 x^{2}+0,0607 x+0,1672$. Berdasarkan persamaan tersebut diperoleh nilai $x=3,161$, yang menunjukkan bahwa perlakuan konsentrasi kalsium klorida yang optimal terhadap bobot segar bibit padi hitam lokal adalah $\mathrm{CaCl}_{2} 3,161$ \%. Pada $\mathrm{CaCl}_{2}$ 3,161 \% mampu meningkatkan bobot segar bibit, namun semakin besar nilai konsentrasi kalsium klorida tersebut bobot segar bibit semakin turun.

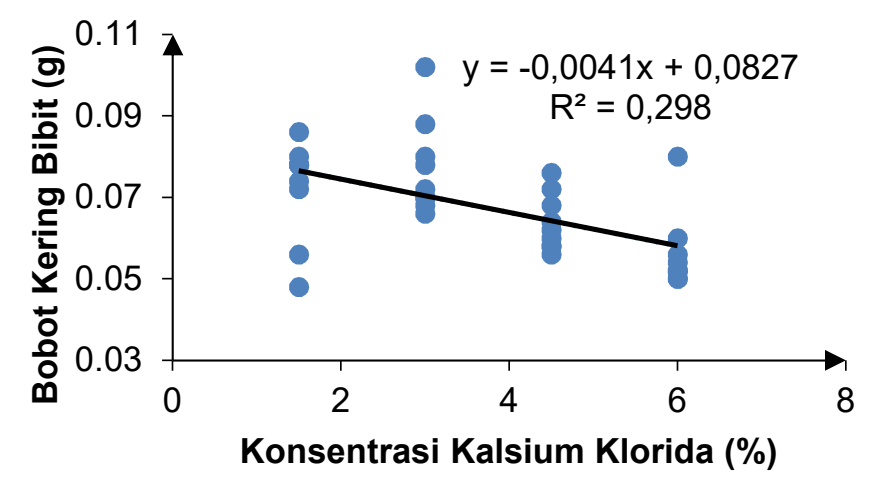

Gambar 2. Pengaruh konsentrasi kalsium klorida terhadap bobot kering bibit 
Pada grafik pengaruh konsentrasi kalsium klorida terhadap bobot kering bibit disajikan pada Gambar 2. Tidak terdapat interaksi antara lama perendaman dan konsentrasi kalsium klorida $\left(\mathrm{CaCl}_{2}\right)$. Dari grafik tersebut dapat dilihat dari regresi yang membentuk pola linier dengan persamaan yaitu $y=-0,0041 x+0,0827$. Grafik tersebut memiliki pola yang secara kecenderungan turun dengan semakin meningkatnya konsentrasi kalsium klorida. Bobot segar dan bobot kering dari bibit akan mencerminkan kondisi fisiologi benih. Apabila mutu fisiologis tinggi, vigor tinggi akan menghasilkan bibit dengan bobot segar dan bobot kering tinggi pula.

Tabel 7. Uji kontras ortogonal umur simpan benih terhadap indeks vigor hipotetik

\begin{tabular}{lccc}
\hline \multicolumn{1}{c}{ Komponen Kontras Ortogonal } & \multicolumn{1}{c}{ Perbandingan rerata IVH } & Keterangan \\
\hline Benih Baru vs Benih Lama & Benih Baru & Benih Lama & \multirow{2}{*}{ tn } \\
Benih lama & 0.911 & 0.997 & \\
(Kontrol vs Perlakuan) & Kontrol & Perlakuan & $*$ \\
& 0.704 & 1.022 & \\
\hline
\end{tabular}

Keterangan: $\left({ }^{*}\right)$ berbeda nyata, $(\mathrm{tn})$ tidak berbeda nyata $(\alpha=5 \%)$.

Berdasarkan hasil uji kontras orthogonal umur simpan benih terhadap indeks vigor hipotetik yang ditunjukkan pada Tabel 7, dapat diketahui bahwa rerata indeks vigor hipotetik dari benih baru dan dari benih lama tidak beda nyata, sedangkan dari hasil uji kontras orthogonal antara benih lama kontrol dengan benih perlakuan kalsium klorida terdapat beda nyata. Guna melihat konsentrasi kalsium klorida yang optimal terhadap indeks vigor hipotetik dilakukan analisis regresi seperti pada Gambar 3.

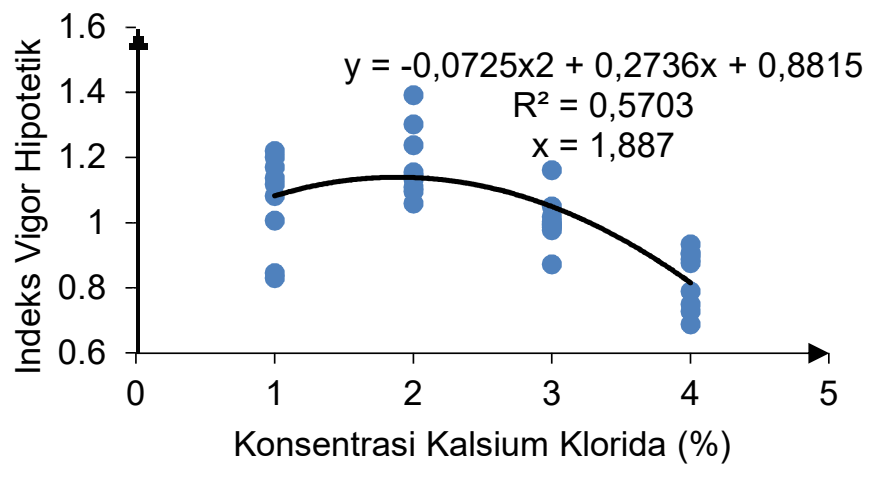

Gambar 3. Pengaruh konsentrasi kalsium klorida terhadap indeks vigor hipotetik

Grafik pengaruh konsentrasi kalsium klorida terhadap indeks vigor hipotetik disajikan pada Gambar 3. Tidak terdapat interaksi antara lama perendaman dan 
konsentrasi kalsium klorida $\left(\mathrm{CaCl}_{2}\right)$ dan hubungan regresi antara konsentrasi kalsium klorida dengan indeks vigor hipotetik terjadi secara nyata. Berdasarkan Gambar 3. tersebut dapat dilihat persamaan dari regresi kuadratik, yaitu $y=-0,0725 x^{2}+0,2736 x+$ 0,8815 . Berdasarkan persamaan tersebut diperoleh nilai $x=1,887$ yang menunjukkan bahwa perlakuan konsentrasi kalsium klorida yang optimal terhadap indeks vigor hipotetik padi hitam lokal adalah $\mathrm{CaCl}_{2}$ 1,887 \%. Pada konsentrasi $\mathrm{CaCl}_{2}$ 1,887 \% mampu meningkatkan indeks vigor hipotetik, namun semakin besar nilai konsentrasi kalsium klorida tersebut indeks vigor hipotetik semakin turun.

Nilai indeks vigor hipotetik berkaitan dengan jumlah daun, diameter batang luas daun, tinggi bibit dan bobot kering bibit, sehingga apabila semakin banyak jumlah daun yang muncul pada bibit, semakin besar diameter batang bibit, semakin besar nilai luas daun dan bobot kering bibit, serta semakin tinggi ukuran tanaman muda, maka nilai indeks vigor hipotetik juga akan semakin besar pula. Selain itu nilai indeks vigor hipotetik tidak terlepas dari viabilitas benih. Benih dengan viabilitas tinggi akan menghasilkan nilai vigor hipotetik yang tinggi pula, dikarenakan vigor hipotetik menggambarkan kemampuan tumbuh benih menjadi bibit. Benih yang mampu berkecambah dengan baik juga akan mampu tumbuh menjadi bibit dengan baik. Semakin lama benih disimpan, vigor hipotetik benih semakin menurun. Hal tersebut dikarenakan benih mengalami kemunduran seiring lamanya penyimpanan (Immawati, 2013).

Pengaruh priming dengan $\mathrm{CaCl}_{2}$ pada perkecambahan benih dapat disebabkan karena kalsium tersebut mempengaruhi terjadinya peningkatan pada ekspresi, stabilitas dan aktivitas enzim $\alpha$-amilase, enzim yang berperan pada perkecambahan benih (Afzal et al., 2012). Selain itu diduga disebabkan karena adanya kandungan antosianin pada benih hitam yang termasuk dalam antioksidan. Keberadaan antosianin yang termasuk dalam antioksidan menurut Tilawah (2013), dapat berguna untuk mempertahankan viabilitas benih karena memiliki kemampuan untuk mengurangi efek radikal bebas yang terbentuk selama penyimpanan. Antioksidan diketahui mampu melindungi dan mencegah terjadinya deteriorasi oksidatif lipid dan menjaga struktur serta fungsi dari sel, dan menurut Moller et al. (2007) enzim antioksidan seperti superoxide dismutase (SOD), catalase (CAT), dan ascorbate peroxidase (APX) berfungsi dalam menangkal ROS. 


\section{KESIMPULAN}

Konsentrasi $\mathrm{CaCl} 2$ pada kisaran 1,887-3,161 \% optimal terhadap parameter bobot segar bibit, bobot kering bibit, dan meningkatkan indeks vigor hipotetik bibit pada benih padi hitam lokal lama, serta lama perendaman 12 jam dengan 1,5 \% CaCl2 memberikan nilai panjang akar terbaik, sedangkan lama perendaman 12 jam dengan $3 \% \mathrm{CaCl} 2$ memberikan nilai terbaik pada diameter batang.

\section{DAFTAR PUSTAKA}

Afzal, I., A. Butt, H. Ur Rehman, S.M.A. Basra, A. Afzal. 2012. Alleviation of salt stress in fine aromatic rice by seed priming. Aust J Crop Sci. 6(10): 1401-1407.

Agus, H. 2007. Budidaya padi secara organik. Penebar Swadaya, Jakarta.

BPTP Yogyakarta. 2017. Sembada Merah dan Sembada Hitam Sumber Daya Genetik Lokal Kabupaten Sleman. <http://yogya.litbang.pertanian.go.id/ind/index.php?option=com_content\&view=artic le\&id=1213:sembada-merah-dan-sembada-hitam-sumber-daya-genetik lokalkabupaten-sleman\&catid=4:info-aktual\&Itemid=174>. Diakses pada tanggal 14 Maret 2018.

Castanares, J.L. and C.A. Bouzo. 2017. Effect of priming on germination and initial growth of melon plants under salt stress. Revista FAVE-Ciencias Agrarias. 16 (2).

Farooq, M., S.M.A. Basra, N. Ahmad. 2007. Improving the performance of transplanted rice. Plant Growth Regul. 51:129-137.

Immawati, D.R., S. Purwanti, D. Prajitno. 2013. Daya simpan benih kedelai hitam (Glycine max (L) Merrill) hasil tumpangsari dengan sorgum manis (Shorgum bicolor (L) Moench). Vegetalika. 2 (4): 25-34.

Kartika dan D.K. Sari. 2015. Pengaruh lama penyimpanan dan invigorasi terhadap viabilitas dan vigor benih padi local Bangka aksesi Mayang. Jurnal Pertanian dan Lingkungan. 8(1): 10-18.

Khan, A.A. 1992. Preplant physiological seed conditioning. Horticultural Reviews. 13(4):131-181.

Kim, W. I., A. Kunhikrishnan, J. Y. Kim, H. S. Kim, J. H. Yoo, N. Cho, and J. H. Hong. 2015. Current mitigation techniques for arsenic and cadmium contaminated paddy soils and rice grains in Korea. <http://www.niaes.affrc.go.jp/marco/marco2015/text/ws3-7_wi_kim.pdf>. Diakses pada tanggal 22 Januari 2017.

Moller, I.M., Jensen, P.E., Hansson, A.. 2007. Oxidative modifications to cellular components in plants. Annu Rev Plant Biol. 58: 459-81.

Singh, I., P.K. Rai, A. Dayal, D.K. Srivastav, N. Kumari, and V. Dugesar. 2017. Effect of pre-sowing invigoration seed treatments on germination behaviour and seedling 
vigour in wheat (Triticum aestivum L.) seeds. Journal of Pharmacognosy and Phytochemistry 6(4): 932-935.

Sutariati, G.A.K., Zul'aiza, S. Darsan, M.A. Kasra, S. Wangadi, L. Mudi. 2014. Invigorasi benih padi gogo lokal untuk meningkatkan vigor dan mengatasi permasalahan dormansi fisiologis pascapanen. Jurnal Agroteknos 4 (1): 10-17.

Tilawah, Resti. 2013. Pengaruh pengusangan cepat dan penyimpanan alami terhadap viabilitas benih beberapa varietas kacang tanah (Arachis hypogaea L.). Fakultas Pertanian. Institut Pertanian Bogor. Skripsi. 